\title{
9 \\ Conclusion: What Followed and What May Yet Proceed
}

Goodna Girls is a living history. Since the collection of these oral histories, Tammy, as part of the 2017 South Burnett Regional Council Australia Day Awards, was awarded two certificates of achievement for her volunteer work. On 1 January 2017, Rose finally moved into a home of her own, provided by the Housing Authority in Western Australia, where she is able to live with her daughter Karen.

In terms of a wider policy response, in 2016, the acting Queensland mental health commissioner read my opinion piece concerning the plight of children sent to Wolston Park Hospital. ${ }^{1}$ Later, she approached the Queensland Government to support a reconciliation process. In an email to me, she explained:

I brought to the attention of the Government, in mid-2016, the promise to consult with people who as wards of the State may have suffered harm while detained in adult mental health facilitiesthis is consistent with the 2010 Apology. As a result, the Minister for Health agreed to progress a process to consult with each of the people that fall within the above definition. ${ }^{2}$

Media attention followed. Meanwhile, the women survivors initiated their own meetings with politicians and bureaucrats to ensure that the consultation process would both be expedient and cognisant of their needs and associated sensitivities. This quest for justice has indeed been

2 Email to author, 6 January 2017. 
survivor driven. In October 2017, Queensland ministers Cameron Dick and Shannon Fentiman wrote to those survivors who had participated in the reconciliation process informing them of the details of a reconciliation plan:

We will provide an ex gratia payment ... in acknowledgement of the wrong that was done to you as a result of the State's decision to place, you, as a child, in an adult mental health facility.

This payment is not intended as compensation. The acceptance of this payment will not stop you from pursuing your common law rights, and therefore we will not ask you to sign a deed of release as a condition of payment.

We understand that some of the other people participating in the reconciliation plan may not want the amount of the ex gratia payment to be known publicly. For this reason we ask that you keep the amount of ex gratia payment confidential. ${ }^{3}$

The letter also noted the Queensland Government's offer to make additional payments of $\$ 1,000$ for legal advice, $\$ 1,000$ for financial advice and $\$ 2,000$ for professional counselling/debriefing sessions. The government promised to identify an organisation or individual to assist survivors with access to government services; provide information on the impact of the antipsychotics, sedatives and anti-anxiety medications they received as children; and provide access to their health records (until the age of 21 years). The government also informed survivors that the Queensland Police Service would only take action in response to testimonies of criminal and potentially corrupt behaviour if survivors made a formal complaint.

Financial redress had been granted 21 years after a group of former child inmates had met through an invitation to connect, made in Ken Blanch's 1996 article in the Brisbane Sunday Mail. Six women from this collective did not live to see this outcome of their years of activism. The significant delay on the part of the Queensland Government to a resolution for former child inmates of Wolston Park Hospital is not the only criticism. The public notification of the reconciliation process was also too narrow. 'Connie', a former state ward who had been placed in Wolston Park Hospital as a child, had only learned of the reconciliation process when it was over. Connie contacted me after the reconciliation process. She wrote:

3 Dick and Fentiman, letter to participants of reconciliation process, 17 October 2017. 
If I wasn't placed on the Government's reconciliation list, and I was definitely placed in Goodna, then how many other girls are there? I never saw any advertisement about it. Not everybody reads the Australian. There may be other women that the Queensland Government has not taken responsibility for. ${ }^{4}$

Connie, as a child, was a victim of domestic abuse and incarcerated in Winlaton Youth Training Centre in Melbourne after she was charged with 'neglect'. Then, after having been taken by her abusive father to Brisbane, she was placed in Karrala House and subsequently transferred to a locked ward in Wolston Park Hospital:

I'd become a sort of nobody-wants-you thing. They drove me mad by putting me in isolation at Karrala and I came out of there in a rage and because of that, they put me in an adult institution for insane people. I was first put into a locked ward in Goodna where I was kept in a straightjacket. Every time I cried I was given a needle of Paraldehyde. I was given enemas. Eventually I was put in an open ward. I was released from Goodna when I turned 18.

I don't want to have to fight for money. I'm on a pension, paying a mortgage and barely surviving. The main thing I want is recognition, not just for me but also for all the women who went through that hell hole. Nothing can compensate for what they did. Nothing. I'm not a nut case but I have depression. I can't get rid of the nightmares. I can't get rid of the daytime flashbacks. I live with it always. I'm 67 years old and I'm still living with it. Why shouldn't we speak up?5

Connie attempted to draw public attention to this living history through writing her own autobiography, which has since been published. She was also interviewed on television. She observed:

The Forde Inquiry was well-advertised. I was living in Western Australia, I heard about it and I put in my submission. The Government didn't look through the records properly as part of the reconciliation process. They also had my name on record because I sent in a submission for the Forde Inquiry. They obviously don't want to know how many women went through hell! ${ }^{6}$

\footnotetext{
'Connie', conversation with author, 19 December, 2017.

'Connie', conversation with author, 19 December, 2017.

'Connie', conversation with author, 19 December, 2017.
} 
Connie's frustration suggests that the research conducted by the Queensland Department of Health in preparation for the reconciliation process lacked rigour or, perhaps, that the government may have purposefully restricted the process to limit the numbers of survivor participants.

Do redress payments denote a sufficient conclusion to this living history? The narratives of the women in this book address the violation of children's rights as well as a suite of crimes committed against children. The reconciliation process was conducted in private but is there also a need for a public hearing? John Murray is a Forgotten Australian who, as a child, experienced 11 years in out-of-home care and became a criminal justice activist and political adviser for three members of state parliament. He was the co-ordinator of the Positive Justice Centre, which campaigned for the rights of young people in institutionalised care. Murray was awarded a Human Rights Award by the Australian Human Rights Commission in 2004. He spoke to me about the reconciliation process administered by the Queensland Department of Health:

There is an assumption that without having a full and frank discussion and understanding of what took place that somehow there will be remarkable change. In addition, the Department of Health - the very same agency that is responsible for the problem is then tasked by the state to respond. That's quite inappropriate. The issue was 'power' then and it's about 'power' now. Instead of sending in another agency, that can have some semblance of independence, the response has to come from the organisation that did the damage. It takes away good faith and takes away power from the victims by recreating the original relationship when these survivors were children. Governments have agencies for these purposes. With just a letter of authority from the minister, they could have used the ombudsman, the privacy commissioner, the attorney general or the law reform commission. There should be an independent judicial review with appropriate processes and experience in dealing with legal and moral concerns-gathering of evidence, taking witness statements, understanding appropriate remedies and writing a report. The only role for the Department of Health is to be an honest participant but not to lead this because they themselves have something to learn. Expediency is attractive and desirable but an independent review could still be quick. ${ }^{7}$

7 John Murray, conversation with author, 23 April, 2017. 
Such a judicial review could, in addition to examining behaviours of individual staff, investigate the decisions of politicians and bureaucrats throughout this chapter of Australian punitive welfarism. As Murray wrote in the Positive Justice Centre's submission (2003) to the Senate Inquiry into Children in Institutional Care: 'We should not allow that breach of the social contract to go unpunished, for the results of that abuse have been simply astounding. ${ }^{8}$

In addition to the lack of public accountability of the decisions made by government bodies that resulted in children being interned in adult psychiatric facilities, the exclusion of this matter from the terms of reference of the Forde Inquiry and the significant delay in reconciling with survivors, there is also an absence of publicly available data. Three of the four former child inmates in this book managed to escape from Wolston Park Hospital. They ran in fear for their lives. What would have happened to these young women had they remained? What of their fellow child inmates left behind? Further research is required to determine the number of children who were placed in Wolston Park Hospital and the corresponding number and dates of discharges or, if applicable, of deaths and associated burial records.

On a broader scale, the current system of out-of-home care for children requires thorough and independent examination, given the research that demonstrates the disadvantaged life prospects for these young people. Providers of the institutionalised 'care' of the women in this book (before they were placed in Wolston Park Hospital) are still being funded to deliver child protection services. ${ }^{9}$ Good Shepherd Australia New Zealand (formerly the Sisters of the Good Shepherd) runs Warana School for children with mental health issues. ${ }^{10}$ The Uniting Church was formed in Australia in 1977 and is a unification of the Methodist, Presbyterian and Congregational churches. ${ }^{11}$ Uniting Care in Queensland, which is part of the Uniting Church, runs foster care, family and youth services. ${ }^{12}$

8 Positive Justice Centre, Submission 122, Senate Inquiry into Children in Institutional Care, 31 July 2003, at Parliament of Australia, 'Submissions Received by the Committee as at 17/3/05', accessed 30 March 2020, www.aph.gov.au/Parliamentary_Business/Committees/Senate/Community_ Affairs/Completed_inquiries/2004-07/inst_care/submissions/sublist.

9 I am indebted to John Murray for this observation.

10 Good Shepherd Australia New Zealand, 'Young People', accessed 16 February 2020, www.good shep.org.au/find-a-service/young-people/.

11 Watson, 'Performing Religion', 331.

12 Uniting Care, 'Services and Support', accessed 16 February 2020, www.unitingcareqld.com.au/ services-and-support. 
The Sisters of Mercy, together with the Christian Brothers and the Sisters of St Joseph have formed MacKillop Family Services, which runs residential homes for children referred through government departments in New South Wales and Victoria. It is time to formally and critically reflect on the cultural values that endure beyond the inquiries into Australia's outof-home care system for children, enabling a nation's trust and tax dollars to be endowed on charitable organisations and government departments that systematically abused children.

Goodna Girls also has implications for our education system in that these women were denied a formal education. Their internal frustration and external rage, then, is not only a response to their captors, it is also a reaction to a learning potential that was left unfostered as well as symptomatic of a justifiable need to be recognised as worthy. If our education policies and practices are to be equitable, they require an understanding that the signifiers of giftedness in children can be mistaken as identical to the trappings of privilege. It is estimated that only $1-3$ per cent of care leavers enrol in higher education in Australia and their completion rates are lower than their non-care peers. The 'Raising Expectations' project aims to develop strategies to encourage care leavers to access higher education and support those already enrolled. ${ }^{13}$ There is an opportunity in Australia for higher visibility and take-up of education programs that have been designed in consultation with, and specifically target, those who have experienced out-of-home care.

The events that led to the women in this book being placed in Wolston Park may not be explained solely by the notion of the Stolen Generations that emerged in 1982 as a result of Peter Read's published monograph. His research revealed the practice of attempted cultural genocide as a result of intervening visits by government representatives who took Aboriginal children away from their families. ${ }^{14}$ However, Judy and Jean/ Erin did not become aware of their Indigeneity until they were well into their adult years. It is fair to assume that government child protection services at the time did not know that they were Aboriginal either and therefore their Aboriginality was not the direct cause of their being taken into care. Tammy's transition to Wolston Park occurred during the time that she lived with her adoptive non-Indigenous mother, and Rose is non-Indigenous. These observations do not necessitate a revision of Peter

13 Wilson, Harvey and Mendes, 'Changing Lives', 575-76.

14 Read, 'The Stolen Generations'. 
Read's thesis. Instead, it is important to additionally acknowledge the wider policies and legislative instruments that enable both Indigenous and non-Indigenous children to be placed in out-of-home care. This, in turn, should inform relevant and inclusive policy responses in the areas of law, social services and education as well as meaningful and inclusive representation in public history.

On 20 October 2016, Judy and Jean/Erin, as part of their determined quest for redress, met with Shannon Fentiman, Minister for Communities in the Queensland Government. Erin spoke about her childhood experience in solitary confinement - the rape, the torture, the neglect and the punitive medical treatment. She has since been offered an ex gratia payment as part of the reconciliation process. Her words still resound as a cry for the end of punitive responses to vulnerable people:

You have inherited righting the wrongs of the past that both sides of government knew about and were complicit in.

It is cruel what happened to us but it is also cruel what is being done to us now by making us fight for so long.

It is time to finish it. ${ }^{15}$

15 Jean/Erin, email to author, 18 June 2017. 
This text is taken from Goodna Girls: A History of Children in a Queensland Mental Asylum, by Adele Chynoweth, published 2020 by ANU Press, The Australian National University, Canberra, Australia.

doi.org/10.22459/GG.2020.09 